\title{
Seismic Design Assessment of Bridge Piers Location Effect on the Structural Capacity of Supports under Earthquake Action
}

\author{
Ali Fadhil Naser*, Hussam Ali Mohammed, Ayad Ali Mohammed \\ Al-Mussaib Technical College, Al-Furat Al-Awsat Technical University, Babylon City 51006, Iraq
}

Corresponding Author Email: com.ali3@atu.edu.iq

https://doi.org/10.18280/ijsse.110203

Received: 25 March 2021

Accepted: 15 April 2021

\section{Keywords:}

bridges, seismic design, demand, capacity, displacement, frequency

\begin{abstract}
The objective of this study was to assess the seismic performance of two types of bridges structures under effect of earthquake by using different locations and numbers of piers. The results of D/C ratio showed that simply supported I girder bridge appeared higher structural capacity than continuous box girder bridge which was resisted the seismic demand. Continuous box girder bridge had higher seismic demand and lower structural capacity comparing with simply supported I girder bridge. Commonly, the seismic design for two types of bridges models with increasing of piers numbers was suitable to resist the earthquake action for region type B. The results of non-linear static analysis (pushover method) showed that the increasing of piers numbers had significant effects on the seismic design of bridges structures to increase the displacement capacity, force capacity, and decreasing of seismic demand to reduce the effects of earthquake action on the bridges structural members. The bridge type simply supported I girder had higher capacity in longitudinal direction than continuous box girder bridge. Whereas, for continuous box girder bridge appeared higher capacity in transverse direction than simply supported I girder. The performance points which were based on displacement were decreased with increasing the piers numbers for bridges structures supports.
\end{abstract}

\section{INTRODUCTION}

Earthquake is vibrating of the earth layers and it is resulting in unexpected release of energy in earth lithosphere which is leaded to provide seismic waves. According to geological inspection and historical records, it can be estimated the location of the big earthquakes which will happen in next years. Therefore, the earthquake resistant design has significant effects in the design of civil structures. Seismic evaluation becomes a necessary method for existing structures in seismic areas and it can be determined the expected seismic hazard. There are some factors make the structural members capacity assessment undefined such as the building typology, materials deterioration, and the environment of earthquakes. Generally, suitable seismic behavior of the civil structures must be investigated after the happening of strong earthquakes [1-3].

A bridges structures frequently afford a vibrant association to earthquake ravaged areas. Therefore, critical bridges can stay work and efficient even after the earthquake action is finished because of it can provide relief as well as for security and defense objective. Generally, bridge structure includes different structural members such as superstructure members, substructure members, and foundation. The structural performance of the substructure is important to increase the performance of the bridge structure when it is subjected to the earthquake action. The importance of substructure of bridge can be seen that which is represented the link between natural ground and superstructure of bridge. Substructure consists of one piers or more depending on the length and width of superstructure of bridge. According to past inspections in earthquake area, the damage due to earthquake has occurred at piers of bridges. There are some methods can be used to study the seismic performance of bridge structure such as response spectrum and non-linear static analysis [4-6].

Earthquake can be damaged the bridge structure and causes the collapse of a bridge residences people on or below the bridge at hazard. Therefore, it must be substituted or repaired after the earthquake unless another transportation route are recognized. There are many numbers of bridges were designed and constructed by using bridges codes do not contain on seismic design requirements. Therefore, these bridges will suffer from severe damages and structural problems when it is subjected to earthquake event. The responsibility and site situations has significant effects on the performance of bridge structure under [7-10].

In bridges, the structural members of substructures such as piers and abutments are the foremost structural members which they are provided the enough resistance to earthquake action. For energy debauchery, ductile behavior is essential during flexure of structural members of superstructure under horizontal seismic loads. Essentially, it means that the development of plastic hinges or flexural yielding is permitted to happen in piers and abutments during severe shaking to carry down the horizontal design forces to adequate levels. There is a noticeable difference in seismic design characteristics of bridges and buildings. The reducing of degree of indeterminacy of bridge structures leads to reduced probable of dispersing energy and load redistribution [11].

Capacity design of bridge structure means that the supports of bridge will yield first and the others parts of piers will stay in elastic state and have not damages when the bridge is subjected to action of earthquake. The joining of supports to 
foundation and to superstructure members are designed to be stronger and stiffer than the supports. Therefore, plastic hinges are expected to form at the ends of the supports under earthquake state [12].

Performance-based seismic design become of concentration to researchers and structural engineers after the effects of earthquakes. This method is based mainly on displacement consideration rather than strength which is used in conventional seismic design methods. It is more accurate to analyze the bridge structure using probabilistic methodology by integrating the indecisions in seismic demand and structure response to better control the seismic performance [13].

Non-linear static analysis method (pushover analysis) is a very employed method in the assessment of seismic design of bridges structures to resist the earthquake action. It is one of the best suitable methods to estimate the seismic safety of structural members for new or old ones. There are many methodologies on the employment and application of nonlinear static analysis method (pushover analysis). These methodologies include different load patterns, the inclusion of higher modes, adaptive load patterns, and force vs. displacement control. All these are aimed to get a capacity curve which is gave good indication on the seismic behavior of the structure. This method can be beneficial when a current structure has absences in seismic resisting capacity [2, 14-17].

Modal analysis method is used in the design and analysis of civil structures which improves the natural mode frequencies and shapes and to identify the dynamic properties. It can be included on the response spectrum analysis which is a method widely used for the design of civil structures in normal conditions or under earthquake action. The objective of this method is to offer rapid calculations of the highest reaction without the needing to perform response history analysis [18, $19]$.

\section{OBJECTIVES OF STUDY}

The objectives of this study are to assess the seismic performance of two types of bridges structures under effect of earthquake by using different locations and numbers of piers, to study effect of using different piers numbers on the seismic performance of continuous and simply supported bridges, to determine the demand and capacity ratio which is used to evaluate the capacity of bridges supports, to determine the displacement capacity curves by using non-linear static analysis according to pushover analysis, to determine the performance points for supports of bridges structure, to investigate difference of the seismic behavior of continuous and simply supported bridges under earthquake action.

\section{FINITE ELEMENT MODELS OF BRIDGES}

CSI bridge ver. 20. 2 is used to develop the three dimension finite element models for the selected bridges structures. Two types of bridges structure are selected in this study depending on types of supports. The first type is a continuous prestressed concrete box girder bridge and the second is an a simply supported prestressed concrete I girder bridge. Depending on the numbers and locations of piers, five models are constructed for each type of bridge. Model No. 1 has one pier, model No. 2 has two piers, model No. 3 has three piers, model No. 4 has four piers, and model No. 5 has five piers. The height of pier is $6 \mathrm{~m}$, the width is $1.5 \mathrm{~m}$, and the length is $1.5 \mathrm{~m}$. The models of piers is concrete type. Table 1 lists the piers numbers and locations. The box girder bridge model consists of three spans and each span has length which is $25 \mathrm{~m}$, then the total length of model is $75 \mathrm{~m}$. The total width of bridge with four traffic lanes. For I girder bridge, the number of spans is three and each span has length $20 \mathrm{~m}$. Therefore, the total length of bridge model is $60 \mathrm{~m}$ and the total width is $16 \mathrm{~m}$. Figure 1 and Figure 2 shows the three dimension models of bridges structures.

Table 1. Piers numbers and locations

\begin{tabular}{ccc}
\hline $\begin{array}{c}\text { Model } \\
\text { Number }\end{array}$ & $\begin{array}{c}\text { Pier } \\
\text { No. }\end{array}$ & $\begin{array}{c}\text { Pier location from right edge of } \\
\text { bridge in transverse direction (Y-axis) }\end{array}$ \\
\hline Model No. & 1 & $@ 8 \mathrm{~m}$ \\
1 & & $@ 4 \mathrm{~m}$ \\
(one pier) & & $@ 12 \mathrm{~m}$ \\
\hline $\begin{array}{c}\text { Model No. } \\
2\end{array}$ & 1 & \\
\cline { 2 - 3 } (two piers) & 2 & $@ 4 \mathrm{~m}$ \\
\hline Model No. & 1 & $@ 8 \mathrm{~m}$ \\
3 & 2 & $@ 12 \mathrm{~m}$ \\
nyy & 3 & $@ 2 \mathrm{~m}$ \\
\hline three piers) & 3 & $@ 6 \mathrm{~m}$ \\
\hline Model No. & 1 & $@ 10 \mathrm{~m}$ \\
4 & 2 & $@ 14 \mathrm{~m}$ \\
(four piers) & 3 & $@ 2 \mathrm{~m}$ \\
\cline { 2 - 3 } & 4 & $@ 5 \mathrm{~m}$ \\
\hline Model No. & 1 & $@ 8 \mathrm{~m}$ \\
5 & 2 & $@ 11 \mathrm{~m}$ \\
\cline { 2 - 3 } (five piers) & 3 &
\end{tabular}

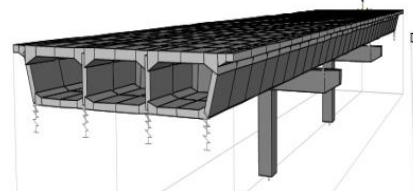

(a) One pier

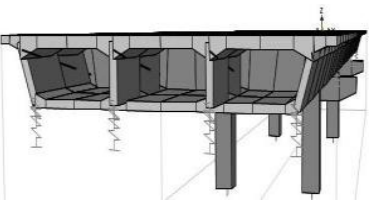

(b) Two piers

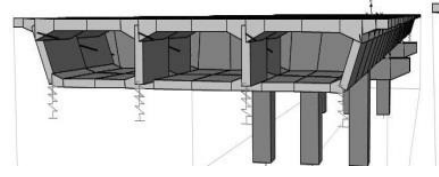

(c) Three piers

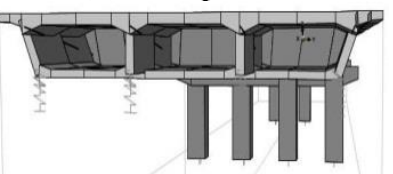

(d) Four piers

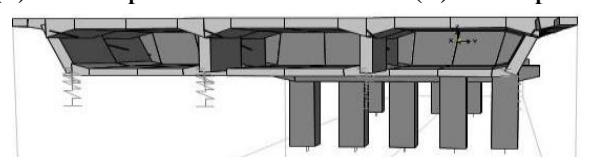

(e) Five piers

Figure 1. Box girder bridge models

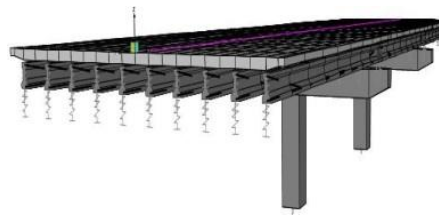

(a) One pier

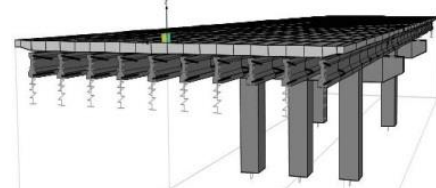

(c) Three piers



(b) Two piers



(d) Four piers 


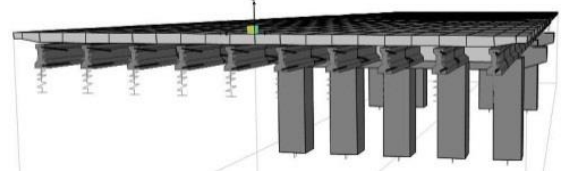

(e) Five piers

Figure 2. I girder bridge models

\section{SEISMIC DESIGN OF DEMAND TO CAPACITY RATIO FOR SUPPORTS 1 AND 2}

The ground movement hazard by adopting the time period and displacement is used according to earthquake zone type B. Seismic demand to capacity ratio is used to assess the seismic capacity of bridges supports under earthquake action. This ratio must be less than 1.0 for structural member which has enough capacity to resist seismic loads in different direction. When demand/capacity ratio is more than 1.0 , indicating that the seismic design for bridge supports needs improvements to reduce seismic demand and increase structural capacity [20, 21]. Table 2 and Table 3 lists the values of demand and capacity ratio for prestressed concrete box girder models with different piers numbers in transverse and longitudinal direction based on seismic displacement. In transverse direction, the values of $\mathrm{D} / \mathrm{C}$ ratio are decreased with increasing of piers numbers for support 1 and support 2. The maximum value is appeared within model which has one pier (0.45) but it is less than 1.0, and the minimum value is existed in model No. 4 (four piers) and model No. 5 (five piers) which is equal to 0.25 . For longitudinal direction, the higher value of $\mathrm{D} / \mathrm{C}$ ratio is 0.73 within model No. 1 (one pier) and this value is decreased with increasing of pier number until model No.5 which has lower value (0.27). Generally, the all values of D/C ratio in transverse and longitudinal direction are less than 1.0 for box girder bridge models supports. Longitudinal direction of bridge supports displacement has higher values of demand comparing with capacity.

The values of D/C ratio for prestressed concrete I girder bridge model in transverse and longitudinal direction are listed in Table 4 and Table 5. From these tables it can be seen that all values of $\mathrm{D} / \mathrm{C}$ ratio for bridge supports in two direction are less than 1.0 and the values of ratio in transverse direction are more than the values in longitudinal direction. In general, the values of $\mathrm{D} / \mathrm{C}$ ratio are decreased with increasing of piers numbers. The higher value in transverse direction is 0.41 within model No. 1 (one pier) and the minimum value is appeared in model No. 5 (five piers) which is 0.25 . for longitudinal direction, the higher value is 0.39 within model No. 1 (one pier) and the lower value is existed in model No. 5 (five piers) which is 0.24 .

Table 2. DC ratio for box girder bridge in transvers direction

\begin{tabular}{ccccccc}
\hline & \multicolumn{3}{c}{ Support No. 1 } & \multicolumn{3}{c}{ Support No. 2 } \\
\cline { 2 - 7 } Model No. & Demand & Capacity & D/C Ratio & Demand & Capacity & D/C Ratio \\
\hline 1 & 0.031 & 0.068 & 0.45 & 0.029 & 0.068 & 0.43 \\
\hline 2 & 0.032 & 0.085 & 0.38 & 0.032 & 0.085 & 0.37 \\
\hline 3 & 0.029 & 0.100 & 0.29 & 0.029 & 0.097 & 0.29 \\
\hline 4 & 0.027 & 0.111 & 0.25 & 0.027 & 0.110 & 0.25 \\
\hline 5 & 0.025 & 0.102 & 0.25 & 0.025 & 0.101 & 0.25 \\
\hline
\end{tabular}

Table 3. DC ratio for box girder bridge in longitudinal direction

\begin{tabular}{ccccccc}
\hline & \multicolumn{3}{c}{ Support No. 1 } & \multicolumn{3}{c}{ Support No. 2 } \\
\cline { 2 - 7 } Model No. & Demand & Capacity & D/C Ratio & Demand & Capacity & D/C Ratio \\
\hline 1 & 0.051 & 0.070 & 0.73 & 0.051 & 0.0703 & 0.73 \\
\hline 2 & 0.051 & 0.112 & 0.45 & 0.051 & 0.112 & 0.45 \\
\hline 3 & 0.050 & 0.143 & 0.35 & 0.050 & 0.143 & 0.35 \\
\hline 4 & 0.049 & 0.165 & 0.30 & 0.049 & 0.165 & 0.29 \\
\hline 5 & 0.048 & 0.177 & 0.27 & 0.048 & 0.177 & 0.27 \\
\hline
\end{tabular}

Table 4. DC ratio for I girder bridge in transvers direction

\begin{tabular}{ccccccc}
\hline & \multicolumn{3}{c}{ Support No. 1 } & \multicolumn{3}{c}{ Support No. 2 } \\
\cline { 2 - 7 } Model No. & Demand & Capacity & D/C Ratio & Demand & Capacity & D/C Ratio \\
\hline 1 & 0.034 & 0.108 & 0.32 & 0.035 & 0.084 & 0.41 \\
\hline 2 & 0.032 & 0.120 & 0.26 & 0.032 & 0.094 & 0.34 \\
\hline 3 & 0.026 & 0.106 & 0.25 & 0.026 & 0.104 & 0.25 \\
\hline 4 & 0.023 & 0.092 & 0.25 & 0.022 & 0.089 & 0.25 \\
\hline 5 & 0.020 & 0.080 & 0.25 & 0.0194 & 0.077 & 0.25 \\
\hline
\end{tabular}

Table 5. DC ratio for I girder bridge in longitudinal direction

\begin{tabular}{ccccccc}
\hline & \multicolumn{3}{c}{ Support No. } & \multicolumn{3}{c}{ Support No. 2 } \\
\cline { 2 - 7 } Model No. & Demand & Capacity & D/C Ratio & Demand & Capacity & D/C Ratio \\
\hline 1 & 0.037 & 0.129 & 0.29 & 0.050 & 0.128 & 0.39 \\
\hline 2 & 0.036 & 0.148 & 0.24 & 0.048 & 0.177 & 0.27 \\
\hline 3 & 0.035 & 0.146 & 0.24 & 0.047 & 0.198 & 0.24 \\
\hline 4 & 0.034 & 0.142 & 0.24 & 0.046 & 0.194 & 0.24 \\
\hline 5 & 0.034 & 0.136 & 0.24 & 0.045 & 0.189 & 0.24 \\
\hline
\end{tabular}


According to above results, it can be concluded that simply supported I girder bridge appeared higher structural capacity than continuous box girder bridge which is resisted the seismic demand. Continuous box girder bridge had higher seismic demand and lower structural capacity comparing with simply supported I girder bridge. Commonly, the seismic design for two types of bridges models with increasing of piers numbers is suitable to resist the earthquake action for region type $\mathrm{B}$

\section{SEISMIC MODEL ANALYSIS}

Seismic model analysis method is used to determine the relation between time and natural frequency under earthquake action for bridge structure by adopting dead load. Natural frequency is important factor in the assessment of stiffness and bearing capacity of bridge structure. Figure 3 and Figure 4 shows the values of seismic natural frequency for six modes of box girder bridge models and I girder bridge models respectively. According to these figures, the seismic natural frequency values are increased with increasing of piers numbers for two types of bridges models, it is mean that the stiffness and bearing capacity of bridges structures are increased when piers numbers are increased under seismic load. Box girder models appeared higher values of seismic natural frequency than I girder models.

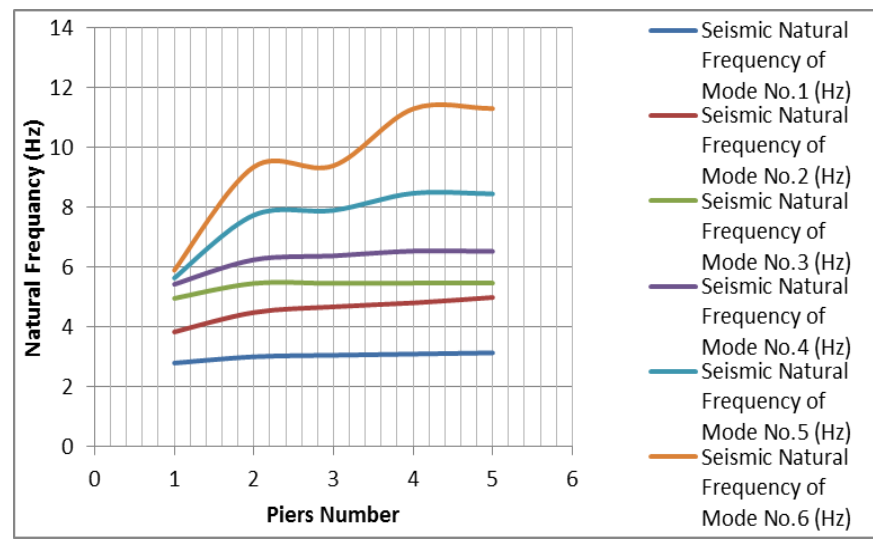

Figure 3. Natural frequency of box girder bridge

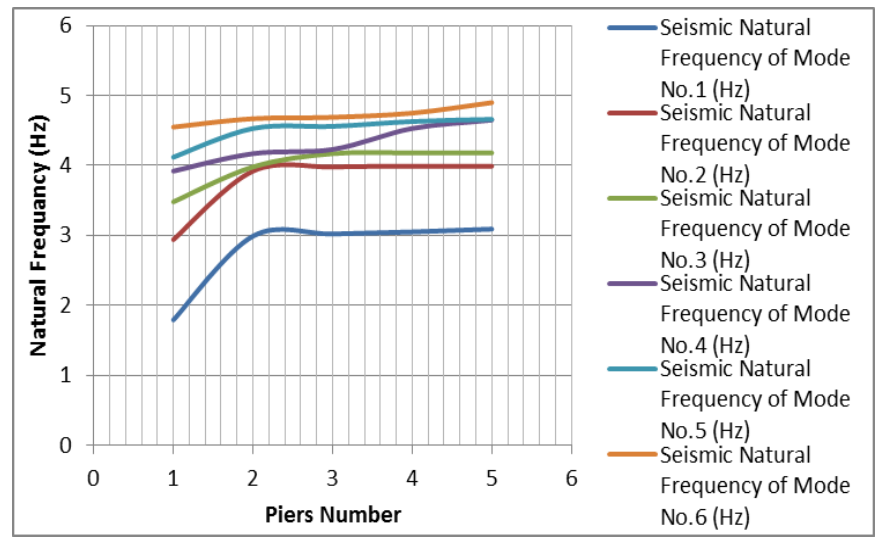

Figure 4. Natural frequency of I girder bridge

\section{NON-LINEAR STATIC ANALYSIS OF SEISMIC DISPLACEMENT CAPACITY}

Seismic displacement is the main parameters in the assessment of seismic design of bridge structure when it is subjected to actions of earth earthquake. In this study, nonlinear static analysis to create the displacement capacity curve under horizontal forces. Yield point on the displacement-force curve is determine for each support of bridge structure in transvers and longitudinal direction. Yield point is represented the displacement capacity of bridge supports and it can be calculated by adopting the point (displacement, horizontal force) on the displacement capacity curve which is located directly after the higher point on the curve.

Table 6, Table 7, Table 8, and Table 9 list the values of yield points (displacement-force) for box girder and I girder bridges in transverse and longitudinal direction respectively. Figure 5 and Figure 6 shows the comparative curves of displacement capacity for support No.1 of box girder bridge models and I girder bridge models. Figure 7 and Figure 8 explains the comparative curves of displacement capacity for support No. 2 of box girder bridge models and I girder bridge models. According to results in Table 6 and Table 7, the displacement capacity and horizontal force capacity points of box girder bridge piers and I girder bridge piers are increased with rising of piers numbers for supports No. 1 and 2. The higher value is appeared within model No. 5 (five piers) which is equal to $(0.096 \mathrm{~m}, 5761 \mathrm{kN})$ and $(0.092 \mathrm{~m}, 5681 \mathrm{kN})$ for supports No. 1 and 2 in transverse direction respectively. For longitudinal direction, the maximum value also is appeared in model No. 5 (five piers) which is equal to $(0.158 \mathrm{~m}, 2256 \mathrm{kN})$ and $0.199 \mathrm{~m}$, $1936.6 \mathrm{kN}$ ) for supports No. 1 and 2 respectively. The higher value of displacement capacity in I girder bridges models in transverse direction is $(0.085 \mathrm{~m}, 7577.5 \mathrm{kN})$ and $(0.089 \mathrm{~m}$, $7544 \mathrm{kN}$ ) for supports No. 1 and 2 respectively, and for longitudinal direction is $(0.151 \mathrm{~m}, 3106.2 \mathrm{kN})$ and $(0.153 \mathrm{~m}$, $3145.8 \mathrm{kN}$ ) for supports No. 1 and 2 respectively. It can be concluded that the increasing of piers numbers has significant effects on the seismic design of bridges structures to increase the displacement capacity, force capacity, and decreasing of seismic demand to reduce the effects of earthquake action on the bridges structural members. Comparative curves of displacement capacity and force capacity indicates that the bridge type simply supported I girder has higher capacity in longitudinal direction than continuous box girder bridge. Whereas, for continuous box girder bridge appears higher capacity in transverse direction than simply supported I girder.

Table 6. Yield points for support No. 1 of box girder bridge

\begin{tabular}{ccc}
\hline $\begin{array}{c}\text { Piers } \\
\text { No. }\end{array}$ & $\begin{array}{c}\text { Displacement - force in } \\
\text { transvers direction }(\mathrm{m}, \\
\mathrm{kN})\end{array}$ & $\begin{array}{c}\text { Displacement-force in } \\
\text { longitudinal direction }(\mathrm{m}, \\
\mathrm{kN})\end{array}$ \\
\hline 1 & $0.085,865.20$ & $0.118,752.70$ \\
\hline 2 & $0.089,3057.4$ & $0.148,1093.2$ \\
\hline 3 & $0.090,3913.3$ & $0.146,1514.2$ \\
\hline 4 & $0.092,4913.7$ & $0.148,1864.8$ \\
\hline 5 & $0.096,5761.0$ & $0.158,2256.0$ \\
\hline
\end{tabular}

Table 7. Yield points for support No. 2 of box girder bridge

\begin{tabular}{ccc}
\hline $\begin{array}{c}\text { Piers } \\
\text { No. }\end{array}$ & $\begin{array}{c}\text { Displacement }- \text { force in } \\
\text { transvers direction }(\mathrm{m}, \\
\mathrm{kN})\end{array}$ & $\begin{array}{c}\text { Displacement-force in } \\
\text { longitudinal direction }(\mathrm{m}, \\
\mathrm{kN})\end{array}$ \\
\hline 1 & $0.073,841.90$ & $0.120,627.80$ \\
\hline 2 & $0.075,2974.7$ & $0.165,935.20$ \\
\hline 3 & $0.077,3829.8$ & $0.180,1277.4$ \\
\hline 4 & $0.077,4805.0$ & $0.194,1619.7$ \\
\hline 5 & $0.092,5681.0$ & $0.199,1936.6$ \\
\hline
\end{tabular}


Table 8. Yield points for support No. 1 of I girder bridge

\begin{tabular}{|c|c|c|}
\hline $\begin{array}{c}\text { Piers } \\
\text { No. }\end{array}$ & $\begin{array}{c}\text { Displacement - force in } \\
\text { transvers direction }(\mathrm{m} \text {, } \\
\mathrm{kN})\end{array}$ & $\begin{array}{c}\text { Displacement-force in } \\
\text { longitudinal direction (m, } \\
\mathrm{kN})\end{array}$ \\
\hline 1 & $0.060,1475.7$ & $0.064,1405.3$ \\
\hline 2 & $0.061,4649.9$ & $0.099,1885.9$ \\
\hline 3 & $0.069,5623.0$ & $0.126,2306.5$ \\
\hline 4 & $0.083,6621.0$ & $0.147,2689.5$ \\
\hline 5 & $0.085,7577.5$ & $0.151,3106.2$ \\
\hline 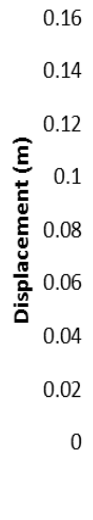 & $2 \underset{\substack{3 \\
\text { Piers No. }}}{4}$ & $\begin{array}{c}- \text { Displacement of box } \\
\text { girder model in } \\
\text { transverse direction } \\
\text { (m) } \\
\text {-Displacement of box } \\
\text { girder model in } \\
\text { longitudinal } \\
\text { direction }(\mathrm{m}) \\
- \text { Displacement of । } \\
\text { girder model in } \\
\text { transverse direction } \\
\text { (m) } \\
* \text { Displacement of I } \\
\text { girder model in } \\
6 \quad \text { longitudinal } \\
\text { direction }(\mathrm{m})\end{array}$ \\
\hline
\end{tabular}

Figure 5. Comparative curves of displacement capacity for support No. 1

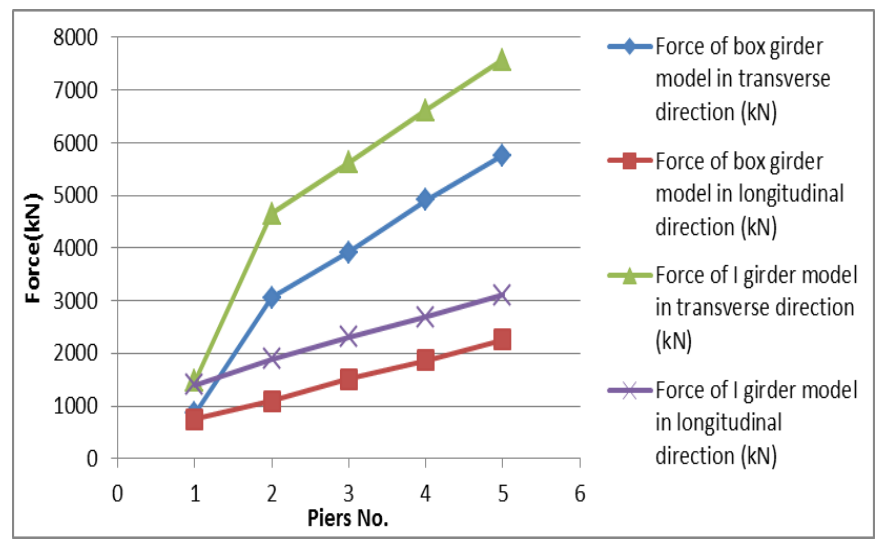

Figure 7. Comparative curves of force capacity for support No. 1

\section{SEISMIC PERFORMANCE POINTS}

Seismic performance points can be obtained by using pushover analysis curves which is the intersection point of capacity spectrum and demand spectrum curves. The performance point on the capacity curve which is located where actual displacement is equal to the estimated target displacement. Three seismic performance points are used in this study. These points include (V, D) point which is represented the shear force (V) and displacement (D), the second performance point is ( $\mathrm{Sa}, \mathrm{Sd}$ ) which is pointed to the spectral acceleration (Sa) and spectral displacement (Sd), and the third performance point is (Teff, Beff) which is indicated to effective period (Teff) and effective damping (Beff) [22-27]. Table 10, 11, 12, 13 lists the abstract of performance points values which is shown in Figures 11 and 12. Figure 9 and Figure 10 shows the performance point $(\mathrm{Sa}, \mathrm{Sd})$ for box girder bridge and I girder bridge models with different piers numbers
Table 9. Yield points for support No. 2 of I girder bridge

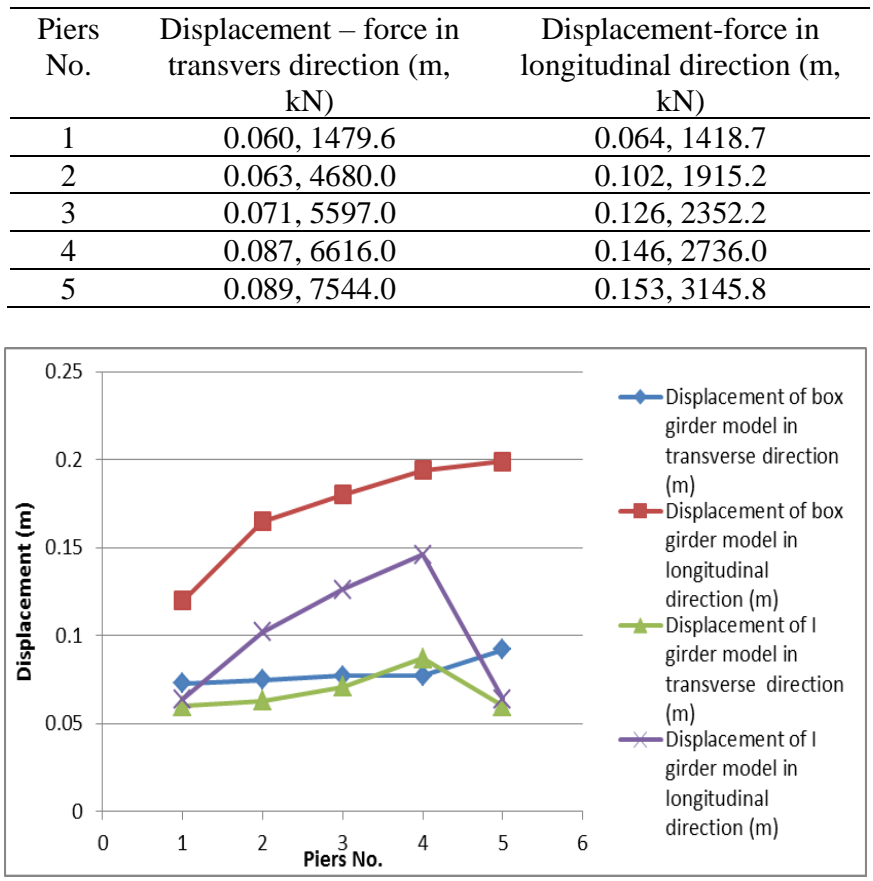

Figure 6. Comparative curves of displacement capacity for support No. 2

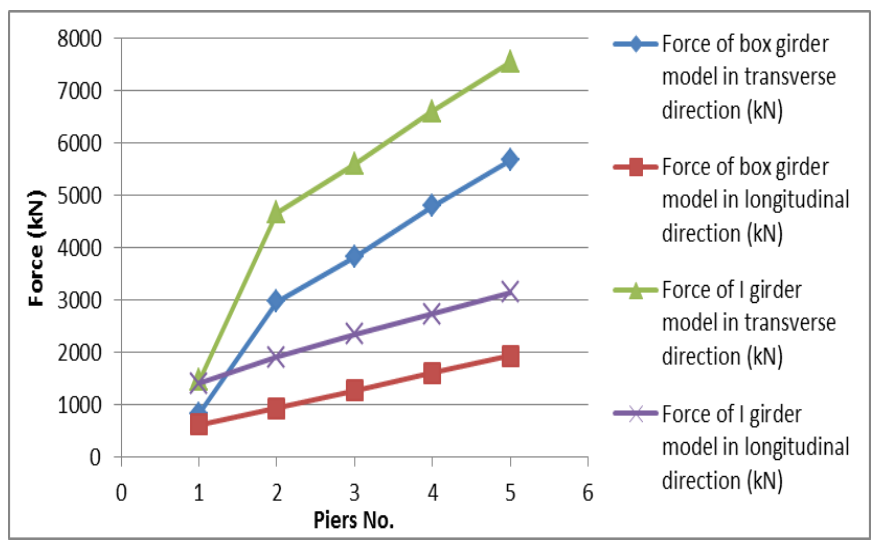

Figure 8. Comparative curves of force capacity for support No. 2

in transverses and longitudinal direction. Figure 11 and 12 shows the performance points for $(\mathrm{V}, \mathrm{D}),(\mathrm{Sa}, \mathrm{Sd})$, and (Teff, Beff) according to CSI bridge for box girder bridge and I girder bridge models with different piers numbers in transverses and longitudinal direction respectively. From Tables and Figures of results it can be explained that the performance points which are based on displacement are decreased with increasing piers numbers. The performance points for model No. 1 (one pier) of box girder bridge in transverse direction are $(\mathrm{V}, \mathrm{D}=580.6 \mathrm{kN}, 0.011 \mathrm{~m}),(\mathrm{Sa}, \mathrm{Sd}=$ $1.0 \mathrm{~g}, 0.011 \mathrm{~m}$ ), and (Teff, Beff=0.207 sec, 0.05), and for longitudinal direction are $(\mathrm{V}, \mathrm{D}=575.9 \mathrm{kN}, 0.012 \mathrm{~m}),(\mathrm{Sa}, \mathrm{Sd}=$ $1.0 \mathrm{~g}, 0.012 \mathrm{~m}$ ), and (Teff, Beff=0.217 sec, 0.05). Whereas, for model No. 5 (five piers), (V, D=1155.5 kN, 0.00211m), (Sa, $\mathrm{Sd}=1.0 \mathrm{~g}, 0.00216 \mathrm{~m}$ ), and (Teff, Beff=0.093 sec, 0.05), and for longitudinal direction are $(\mathrm{V}, \mathrm{D}=1155.5 \mathrm{kN}, 0.0098 \mathrm{~m}),(\mathrm{Sa}$, $\mathrm{Sd}=1.0 \mathrm{~g}, 0.0086 \mathrm{~m}$ ), and (Teff, Beff=0.187 sec, 0.05). I girder bridges models appears higher displacements and effective 
times in transverse and longitudinal direction than box girder bridges models. For transverse direction, the performance points for model No. 1 (one pier) of box girder bridge are $(\mathrm{V}$, $\mathrm{D}=580.6 \mathrm{kN}, 0.016 \mathrm{~m}),(\mathrm{Sa}, \mathrm{Sd}=1.0 \mathrm{~g}, 0.016 \mathrm{~m})$, and (Teff, Beff $=0.257 \mathrm{sec}, 0.05)$, and for longitudinal direction are $(\mathrm{V}$, $\mathrm{D}=577.5 \mathrm{kN}, 0.024 \mathrm{~m}),(\mathrm{Sa}, \mathrm{Sd}=1.0 \mathrm{~g}, 0.018 \mathrm{~m}$ ), and (Teff, Beff $=0.266 \mathrm{sec}, 0.05$ ). Model No. 5 (five piers) has lower values of performance points comparing with Model No.1 (one pier). The performance points for model No. 5 (five piers) of box girder bridge in transverse direction are $(\mathrm{V}, \mathrm{D}=1155.5$ $\mathrm{kN}, 0.00279 \mathrm{~m}),(\mathrm{Sa}, \mathrm{Sd}=1.0 \mathrm{~g}, 0.00284 \mathrm{~m})$, and (Teff, Beff=0. $0.107 \mathrm{sec}, 0.05)$, and for longitudinal direction are $(\mathrm{V}$, $\mathrm{D}=1155.4 \mathrm{kN}, 0.015 \mathrm{~m}),(\mathrm{Sa}, \mathrm{Sd}=1.0 \mathrm{~g}, 0.012 \mathrm{~m})$, and (Teff, Beff $=0.219 \mathrm{sec}, 0.05)$. According to above results, the numbers of piers and location in transverse direction has significant effect on the seismic design of bridge structure supports and their displacements under earthquake action.

Table 10. Performance points for box girder bridge in transverse direction

\begin{tabular}{cccc}
\hline \multirow{2}{*}{ Piers No. } & \multicolumn{3}{c}{ Performance point } \\
\cline { 2 - 4 } & $(\mathrm{V}, \mathrm{D})$ & $(\mathrm{Sa}, \mathrm{Sd})$ & $($ Teff, Beff $)$ \\
\hline 1 & $580.60,0.0110$ & $1.0,0.0110$ & $0.207,0.05$ \\
\hline 2 & $724.3,0.00297$ & $1.0,0.00302$ & $0.110,0.05$ \\
\hline 3 & $868.1,0.00235$ & $1.0,0.00240$ & $0.098,0.05$ \\
\hline 4 & $1011.8,0.00221$ & $1.0,0.00226$ & $0.095,0.05$ \\
\hline 5 & $1155.5,0.00211$ & $1.0,0.00216$ & $0.093,0.05$ \\
\hline
\end{tabular}



(a) One pier in transverse direction

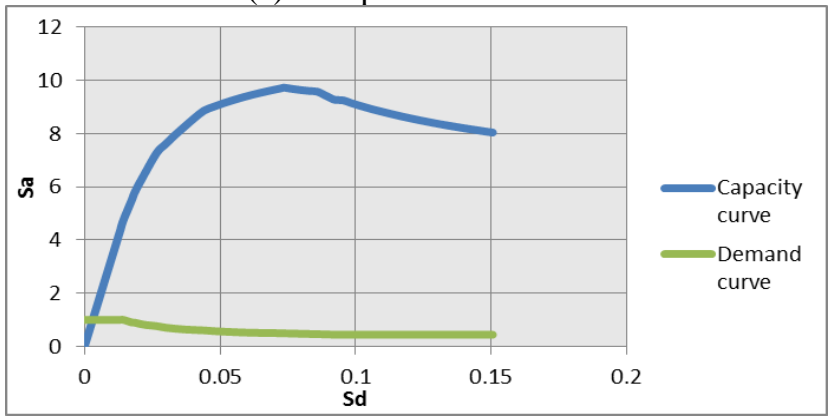

(c) Two piers in transverse direction

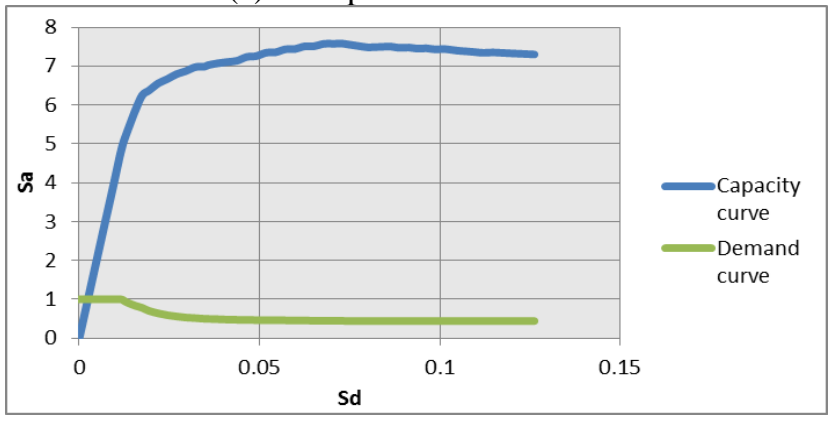

(e) Three piers in transverse direction
Table 11. Performance points for box girder bridge in longitudinal direction

\begin{tabular}{cccc}
\hline \multirow{2}{*}{ Piers No. } & \multicolumn{3}{c}{ Performance point } \\
\cline { 2 - 4 } & $(\mathrm{V}, \mathrm{D})$ & $(\mathrm{Sa}, \mathrm{Sd})$ & $($ Teff, Beff) \\
\hline 1 & $575.9,0.0120$ & $1.0,0.0120$ & $0.217,0.05$ \\
\hline 2 & $721.2,0.0100$ & $1.0,0.00925$ & $0.193,0.05$ \\
\hline 3 & $867.6,0.0100$ & $1.0,0.00890$ & $0.189,0.05$ \\
\hline 4 & $1011.8,0.010$ & $1.0,0.00879$ & $0.188,0.05$ \\
\hline 5 & $1155.5,0.0098$ & $1.0,0.00860$ & $0.187,0.05$ \\
\hline
\end{tabular}

Table 12. Performance points for I girder bridge in transverse direction

\begin{tabular}{cccc}
\hline \multirow{2}{*}{ Piers No. } & \multicolumn{3}{c}{ Performance point } \\
\cline { 2 - 4 } & $(\mathrm{V}, \mathrm{D})$ & $(\mathrm{Sa}, \mathrm{Sd})$ & $($ Teff, Beff) \\
\hline 1 & $580.6,0.0160$ & $1.0,0.0160$ & $0.257,0.05$ \\
\hline 2 & $724.3,0.00392$ & $1.0,0.00397$ & $0.127,0.05$ \\
\hline 3 & $868.1,0.00323$ & $1.0,0.00331$ & $0.115,0.05$ \\
\hline 4 & $1011.8,0.00299$ & $1.0,0.00304$ & $0.111,0.05$ \\
\hline 5 & $1155.5,0.00279$ & $1.0,0.00284$ & $0.107,0.05$ \\
\hline
\end{tabular}

Table 13. Performance points for I girder bridge in longitudinal direction

\begin{tabular}{cccc}
\hline \multirow{2}{*}{ Piers No. } & \multicolumn{3}{c}{ Performance point } \\
\cline { 2 - 4 } & $(\mathrm{V}, \mathrm{D})$ & $(\mathrm{Sa}, \mathrm{Sd})$ & $($ Teff, Beff $)$ \\
\hline 1 & $577.5,0.024$ & $1.0,0.018$ & $0.266,0.05$ \\
\hline 2 & $724.3,0.021$ & $1.0,0.014$ & $0.234,0.05$ \\
\hline 3 & $867.5,0.020$ & $1.0,0.013$ & $0.229,0.05$ \\
\hline 4 & $1011.8,0.016$ & $1.0,0.012$ & $0.224,0.05$ \\
\hline 5 & $1155.4,0.015$ & $1.0,0.012$ & $0.219,0.05$ \\
\hline
\end{tabular}

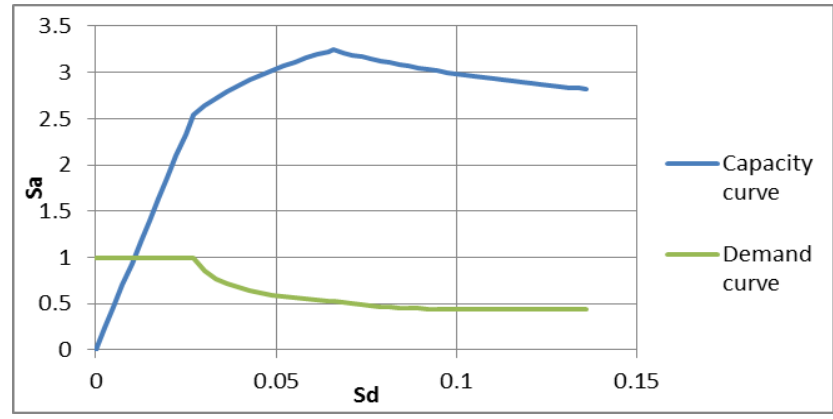

(b) One pier in longitudinal direction

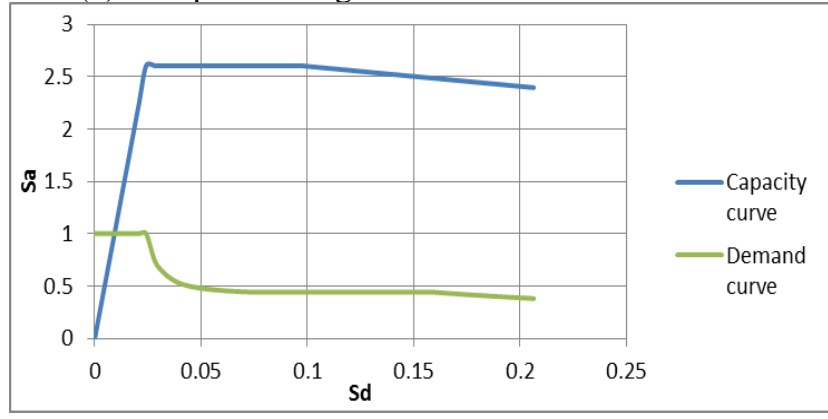

(d) Two piers in longitudinal direction

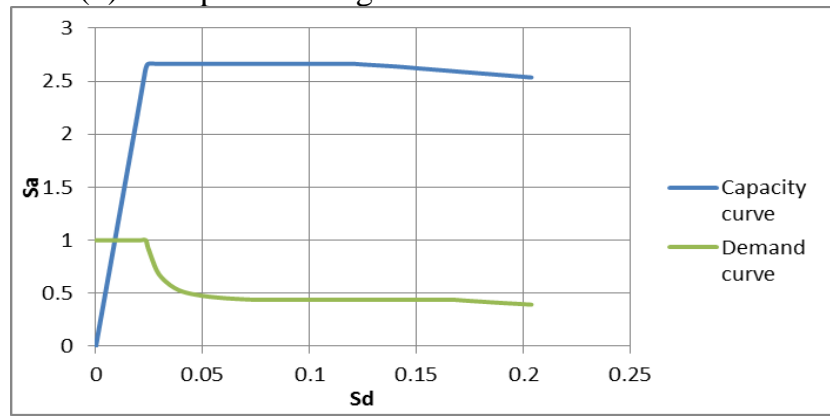

(f) Three piers in longitudinal direction 




(g) Four piers in transverse direction

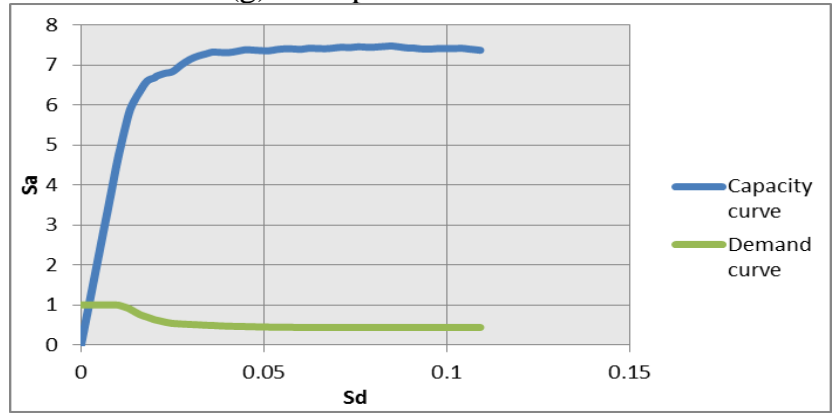

(i) Five piers in transverse direction



(h) Four piers in longitudinal direction

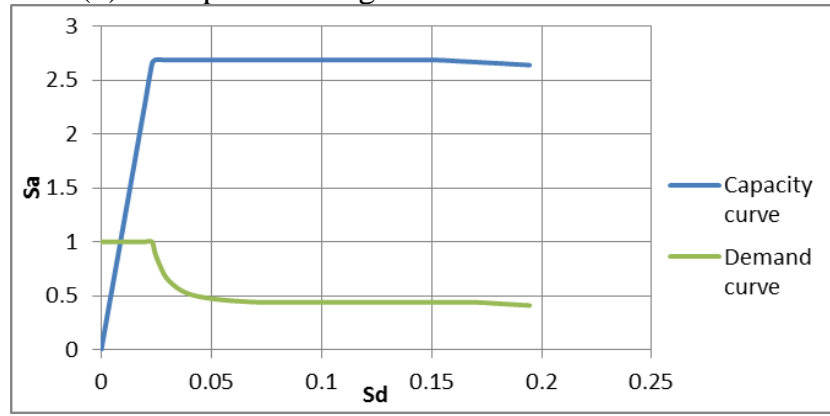

(j) Five piers in longitudinal direction

Figure 9. Performance points (Sa, $\mathrm{Sd}$ ) of supports for box girder bridge models

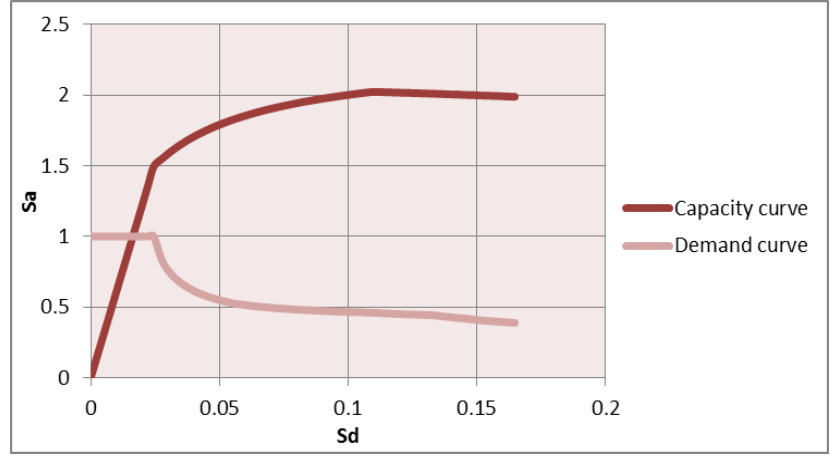

(a) One pier in transverse direction

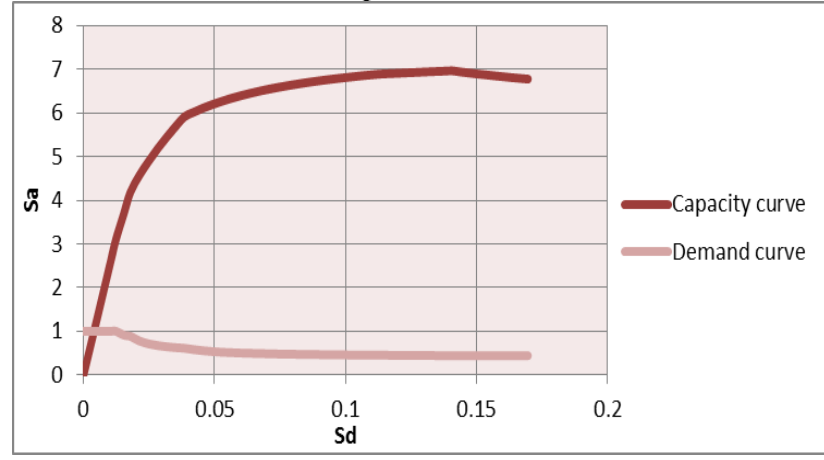

(c) Two piers in transverse direction



(e) Three piers in transverse direction

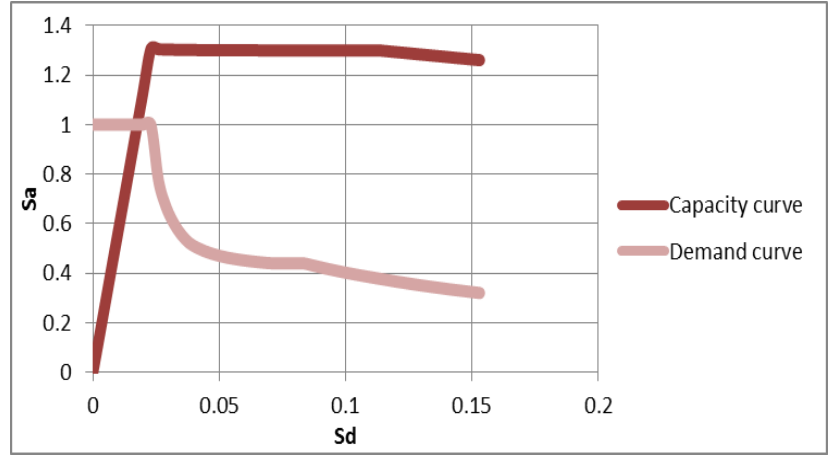

(b) One pier in longitudinal direction

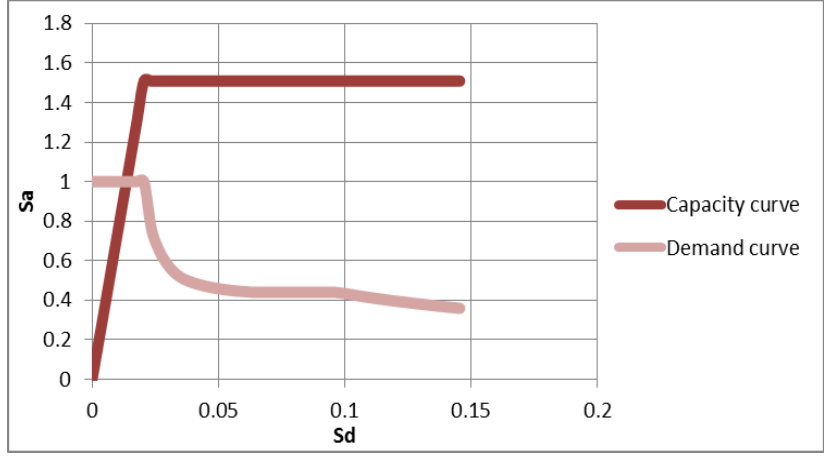

(d) Two piers in longitudinal direction



(f) Three piers in longitudinal direction 


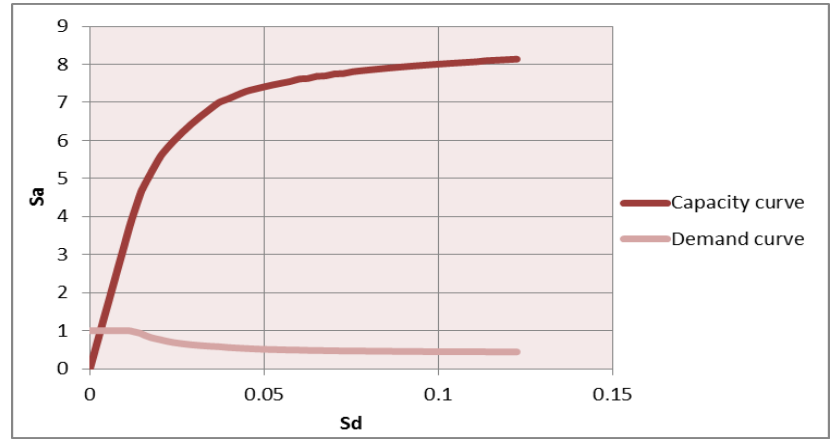

(g) Four piers in transverse direction

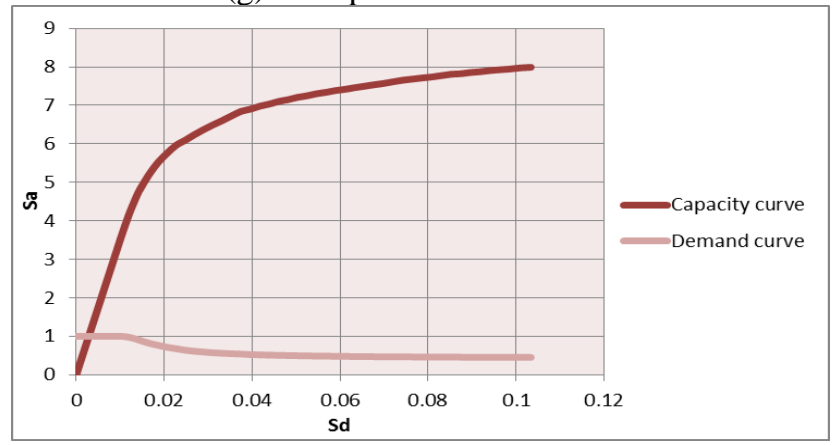

(i) Five piers in transverse direction

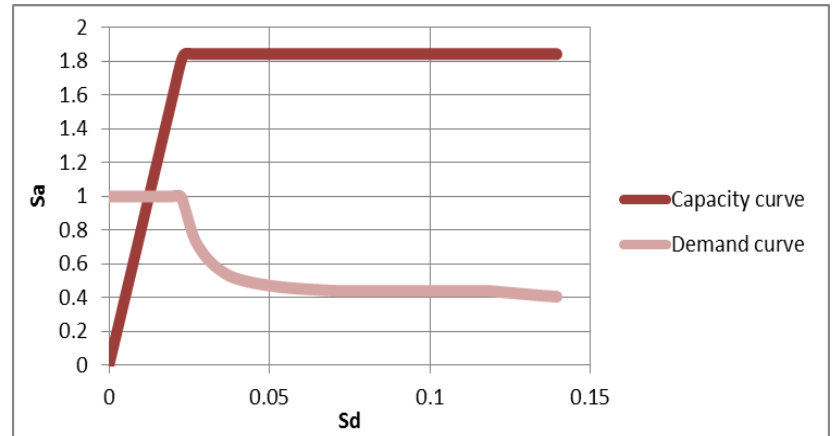

(h) Four piers in longitudinal direction

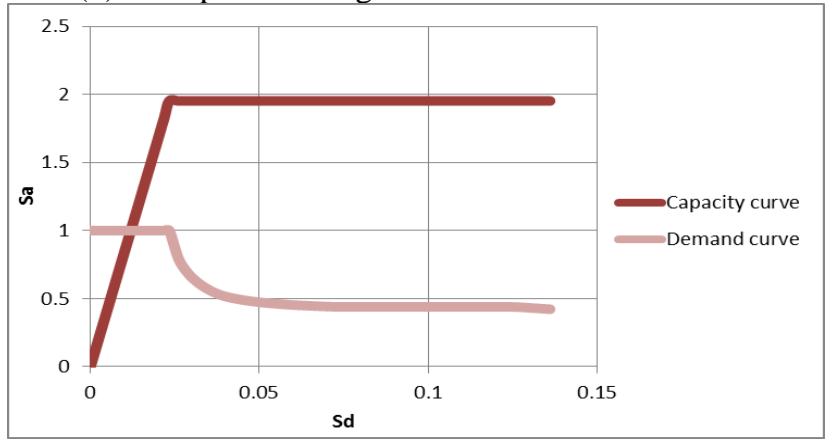

(j) Five piers in longitudinal direction

Figure 10. Performance points ( $\mathrm{Sa}, \mathrm{Sd}$ ) of supports for I girder bridge models

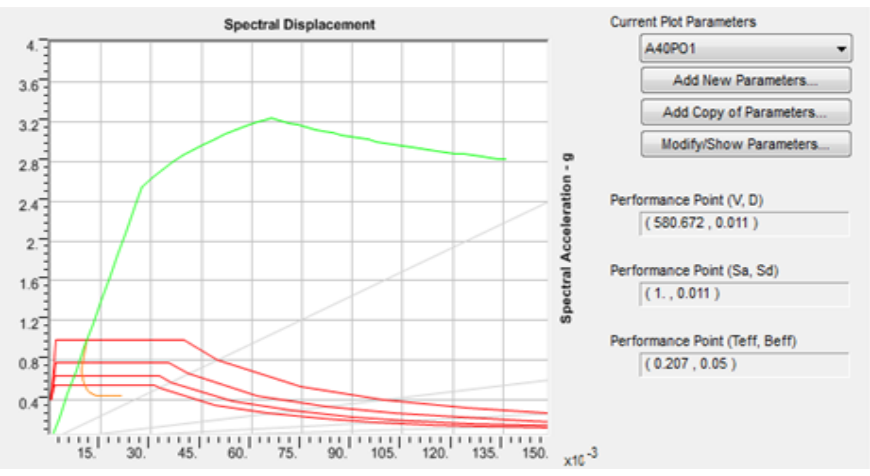

(a) One pier in transverse direction

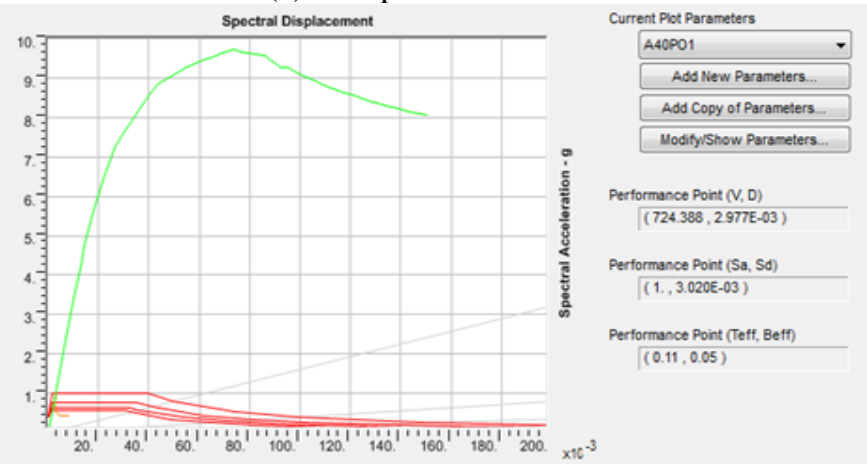

(c) Two piers in transverse direction

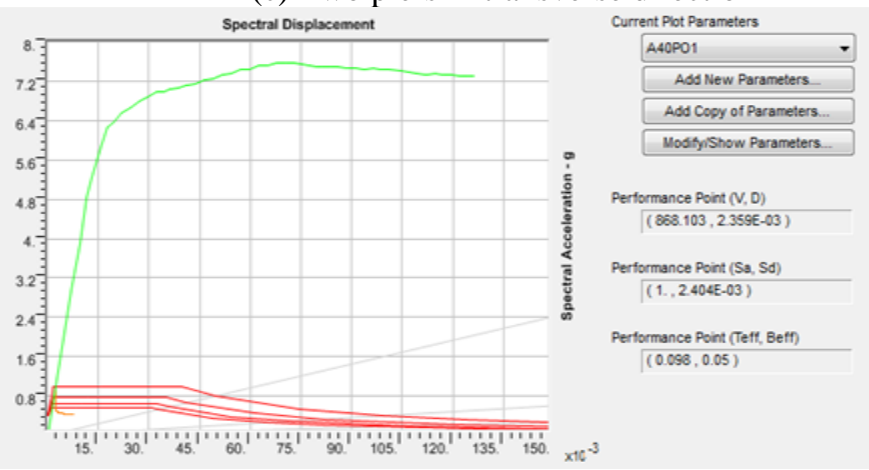

(e) Three piers in transverse direction

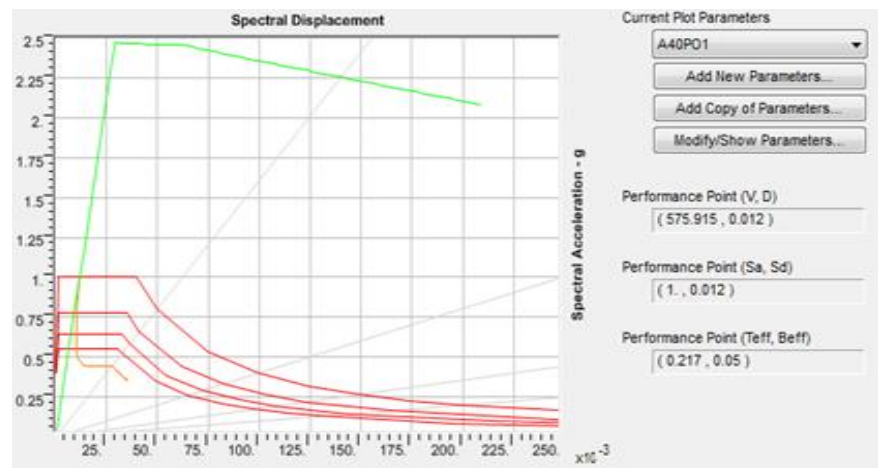

(b) One pier in longitudinal direction

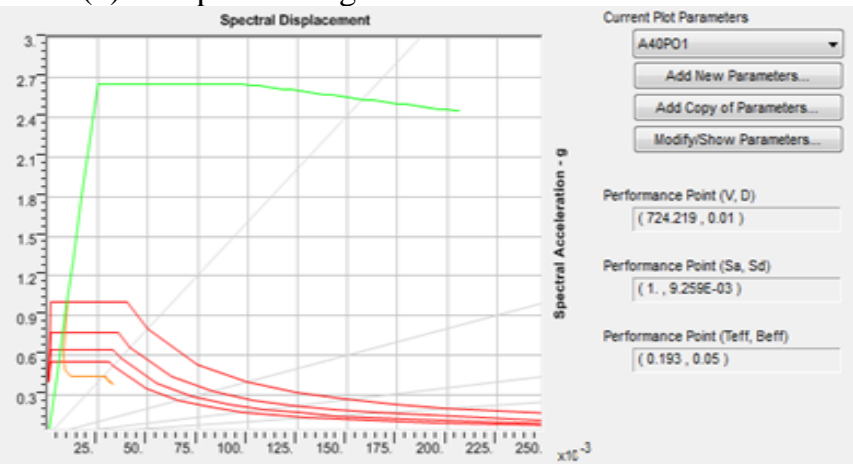

(d) Two piers in longitudinal direction

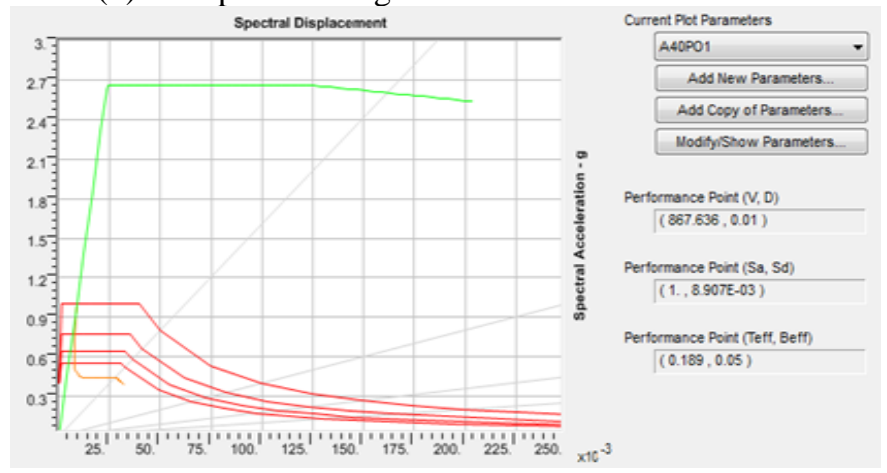

(f) Three piers in Longitudinal direction 


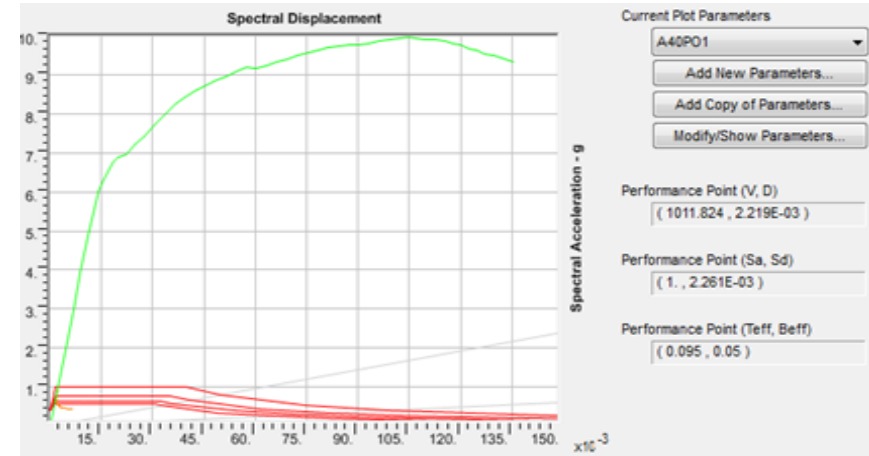

(g) Four piers in transverse direction

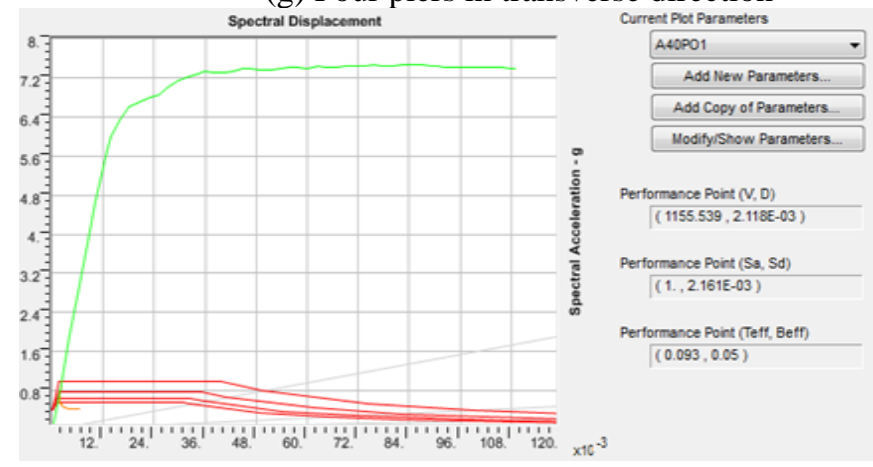

(i) Five piers in transverse direction

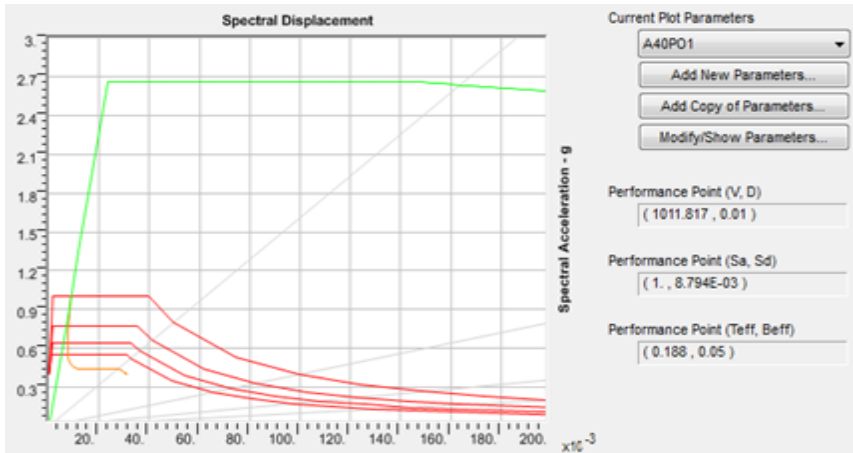

(h) Four piers in longitudinal direction

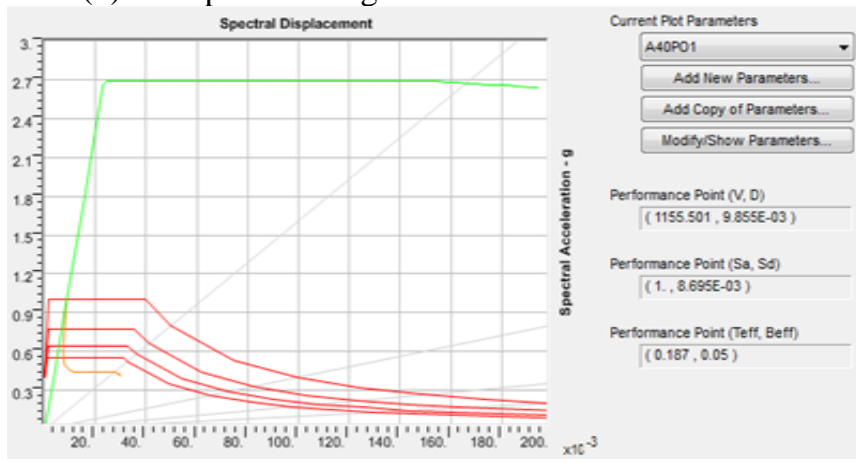

(j) Five piers in Longitudinal direction

Figure 11. Performance points of supports for box girder bridge models



(a) One pier in transverse direction

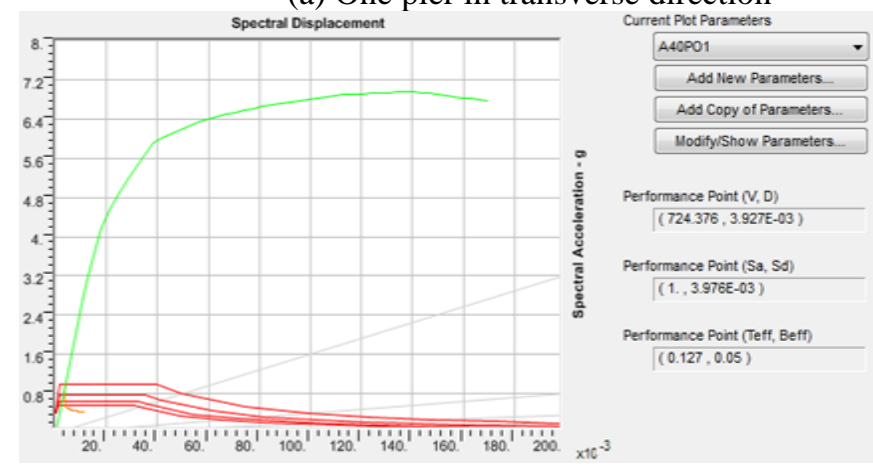

(c) Two piers in transverse direction

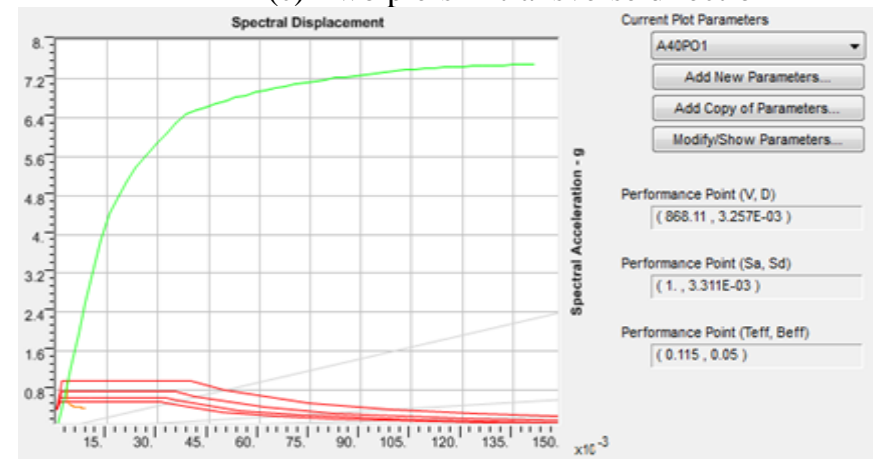

(e) Three piers in transverse direction

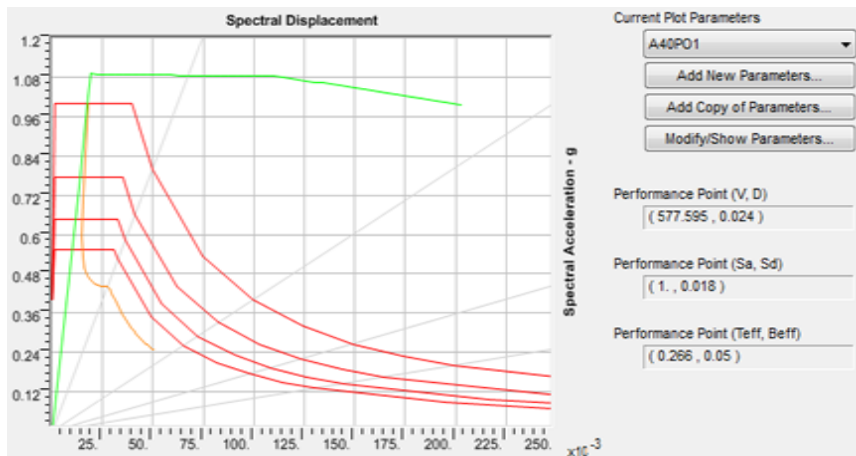

(b) One pier in longitudinal direction

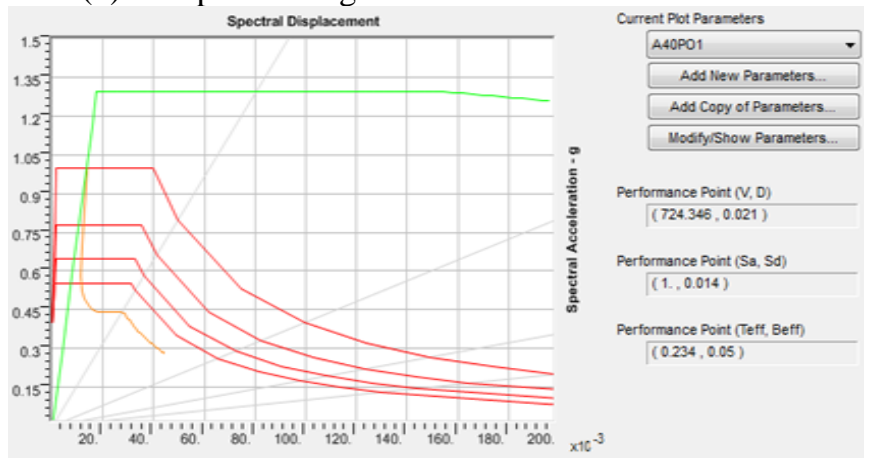

(d) Two piers in longitudinal direction

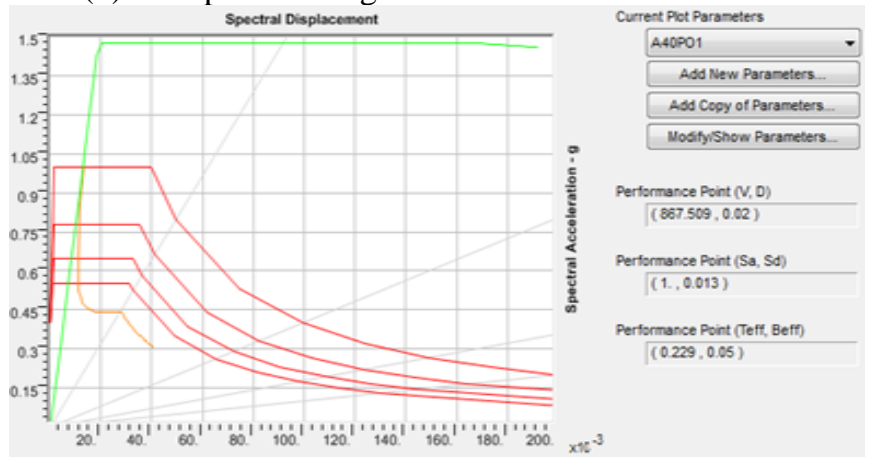

(f) Three piers in Longitudinal direction 


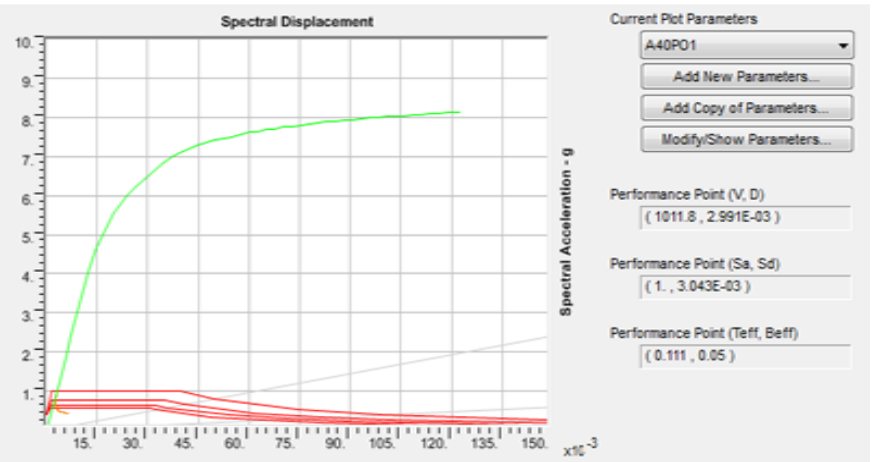

$(\mathrm{g})$ Four piers in transverse direction

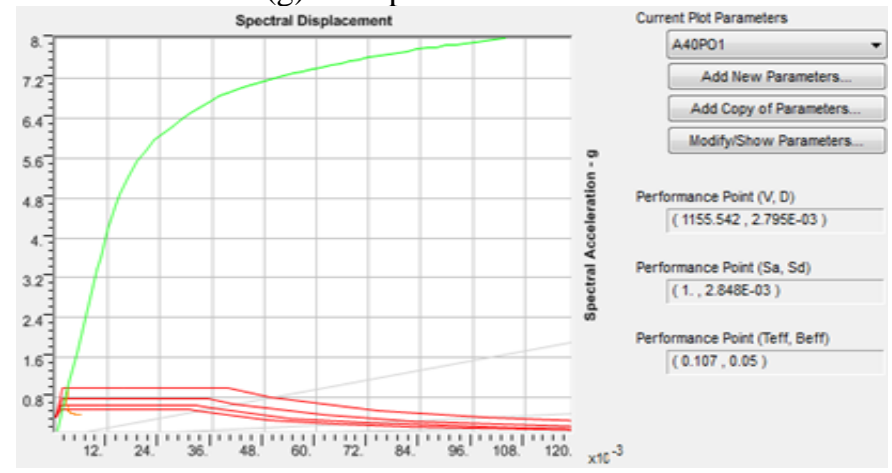

(i) Five piers in transverse direction

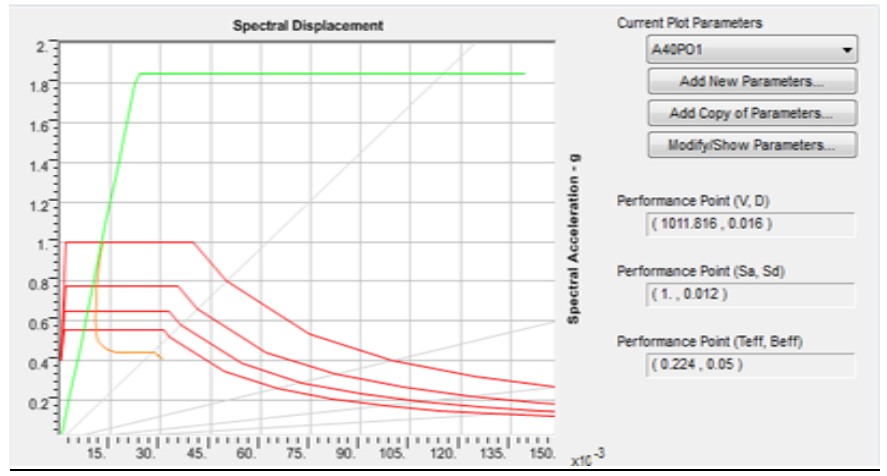

(h) Four piers in longitudinal direction

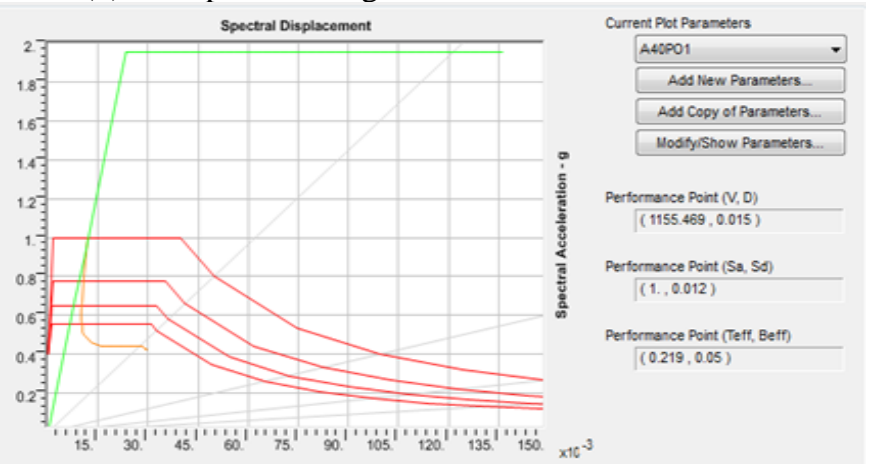

(j) Five piers in Longitudinal direction

Figure 12. Performance points of supports for I girder bridge models

\section{CONCLUSIONS}

The conclusions of this study are:

1. Two types of bridges were selected to study and assess the effect of increasing piers number within bridges substructures in transverse direction on the seismic properties of bridges supports under earthquake action. These types of bridges were continuous prestressed concrete box girder bridge and prestressed concrete simply supported I girder bridge. Five bridges models were used for each type of bridge depending on piers numbers. Model No. 1 had one pier, model No. 2 had two piers, model No. 3 had three piers, model No. 4 had four piers, and model No. 5 had five piers.

2. Three types of methods were used to assess the seismic design parameters of selected bridges by using CSI bridge ver. 20. 2. These methods include demand /capacity ratio, seismic modal analysis, non-linear static analysis which was used to find yield points and performance points.

3. The results of $\mathrm{D} / \mathrm{C}$ ratio showed that simply supported I girder bridge appeared higher structural capacity than continuous box girder bridge which was resisted the seismic demand. Continuous box girder bridge had higher seismic demand and lower structural capacity comparing with simply supported I girder bridge. Commonly, the seismic design for two types of bridges models with increasing of piers numbers was suitable to resist the earthquake action for region type $\mathrm{B}$.

4. According to seismic modal results, the seismic natural frequency values were increased with increasing of piers numbers for two types of bridges models, it was mean that the stiffness and bearing capacity of bridges structures were increased when piers numbers were increased under seismic load. Box girder models appeared higher values of seismic natural frequency than I girder models.

The results of non-linear static analysis (pushover method) showed that the increasing of piers numbers had significant effects on the seismic design of bridges structures to increase the displacement capacity, force capacity, and decreasing of seismic demand to reduce the effects of earthquake action on the bridges structural members. Comparative curves of displacement capacity and force capacity indicates that the bridge type simply supported I girder had higher capacity in longitudinal direction than continuous box girder bridge. Whereas, for continuous box girder bridge appears higher capacity in transverse direction than simply supported I girder. The performance points which were based on displacement were decreased with increasing the piers numbers for bridges structures supports.

\section{REFERENCES}

[1] Anurag, D.P. (2018). Performance based seismic evaluation of medium rise 3D bare frame. Journal of Emerging Technologies and Innovative Research, 5(9): 227-232.

[2] Rafael, S. (2021). Implementation of pushover analysis for seismic assessment of masonry towers: Issues and practical recommendations. Buildings, 11(2): 1-22. https://doi.org/10.3390/buildings11020071

[3] Angulo, C., Díaz, K., Gutiérrez, J.M., Prado, A., Casadey, R., Pannillo, G., Muñoz-La Rivera, F., Herrera, R.F., Vielma, J.C. (2020). Using BIM for the assessment of the seismic performance of educational buildings. International Journal of Safety and Security Engineering, 10(1): 77-82. https://doi.org/10.18280/ijsse.100110

[4] Lande, P., Yawale, D. (2014). Seismic performance 
study of bridge using pushover analysis. International Journal of Mechanical and Production Engineering, 2(8): 50-53.

[5] Parimal, A.G. (2013). Seismic performance study of Urban bridges using non-linear static analysis. International Journal of Innovative Research in Science, Engineering and Technology, 2(6): 2440-2447.

[6] Fajfar, P. (1999). Capacity spectrum method based on inelastic demand spectra. Earthquake Engineering and Structural Dynamics, 28(9): 979-993. https://doi.org/10.1002/(SICI)10969845(199909)28:9<979::AID-EQE850>3.0.CO;2-1

[7] Jack, P.M., Marc, O. (2000). Earthquake Damage to Bridges, Chapter 34, Bridge Engineering Handbook. Ed. Wai-Fah Chen and Lian Duan. CRC Press.

[8] Vaidya, S., Nichat, K. (2020). A Modal pushover analysis on multi-span bridge to evaluate seismic responses. International Journal of Engineering Research \& Technology, 9(6): 193-196. https://doi.org/10.17577/IJERTV9IS060218

[9] Amaladosson, R.E. (2014). Analysis of T-beam bridge for seismic characterization. NZSEE Conference, pp. 111.

[10] Kim, S., D’Amore, E. (1999). Push-over analysis procedure in earthquake engineering. Earthquake Spectra, 15(3): 417-434. https://doi.org/10.1193/1.1586051

[11] Tandon, M. (2005). Economical design of earthquakeresistant bridges. ISET Journal of Earthquake Technology, 42(1): 13-20.

[12] Jonathan, M., David, G., John, F., Marc, O. (2005). Design of precast concrete piers for rapid bridge construction in seismic regions. Final Research Report, Bridge Rapid Construction, Department of Civil and Environmental Engineering University of Washington Seattle, Washington, USA.

[13] Amarjeet, S., Saiid, S. (2014). Probabilistic damage control approach for seismic design of bridge columns. Final Report No. CA14-2280, CCEER 14-02, University of Nevada, RenoDepartment of Civil and Environmental Engineering, USA.

[14] Ahul, L. (2012). The pushover analysis in its simplicity. https://www.researchgate.net/publication/323607343_T he_Pushover_Analysis_in_its_Simplicity.

[15] Federal Emergency Management Agency. (2000). Prestandard and Commentary for the Seismic Rehabilitation of Buildings; FEMA: Washington, DC, USA.

[16] European Committee for Standardization. (2014).
Design of Structures for Earthquake Resistance-Part 1; Eurocode 8: CEN: Brussels, Belgium, Volume 3.

[17] Ismaeil, M. (2018). Seismic capacity assessment of existing RC building by using pushover analysis. Civil Engineering Journal, 4(9): 2034-2043. https://doi.org/10.28991/cej-03091136

[18] Nikolaos, N., John, H., Konstantinos, D. (2015). Modal analysis. Encyclopedia of Earthquake Engineering, chapter, pp. 1-22.

[19] Fragiadakis, M. (2013). Response spectrum analysis of structures subjected to seismic actions. Encyclopedia of Earthquake Engineering. Springer, Berlin, Heidelberg. https://doi.org/10.1007/978-3-642-36197-5_133-1

[20] Alperen, O. (2016). Seismic design of a prestressed concrete bridge. Master thesis submitted to the Graduate Faculty of the University of New Orleans.

[21] Priestley, M., Calvi, G. (1996). Seismic Design and Retrofit of Bridges. Engineering Handbook, John Wiley \& Sons, Inc.

[22] https://knowledge.autodesk.com/support/robotstructural-analysis-products/learnexplore/caas/CloudHelp/cloudhelp/2015/ENU/Robot/fil es/GUID-B5AE1743-D403-4F85-83A0-

135C9A82AD8F-htm.html, accessed on 12 December 2020.

[23] ATC. (1996). Seismic evaluation and retrofit of concrete buildings. Report ATC-40. Redwood City (CA): Applied Technology Council.

[24] Vysakh, Y., Bindhu, K. (2013). Determination of performance point in capacity spectrum method, Energy and Environment conference. Department of Civil Engineering and Mechanical Engineering of Rajiv Gandhi Institute of Technology, Kottayam, Kerala, India.

[25] Ahamed, S., Kori, J.G. (2013). Performance based seismic analysis of an unsymmetrical building using pushover analysis. International Journal of Engineering Research, 1(2): 100-110.

[26] Swathi, S., Venkataramana. K., Rajasekaran, C. (2018). Evaluation of performance point of structure using capacity spectrum method. Applied Mechanics and Materials, 877: 299-304. https://doi.org/10.4028/www.scientific.net/AMM.877.2 99

[27] Leslie, R., Naveen, A. (2017). A study on pushover analysis using capacity spectrum method based on Eurocode 8. 16th World Conference on Earthquake Engineering, Santiago Chile, January 9th to 13th 2017. 